\title{
AN ECO-FURNACE FOR WARMING POULTRY HOUSES USING AGRICULTURAL RESIDUES
}

\author{
EL-Shabrawy. T.H. ${ }^{\text {, }}$, and M. A. Al-Rajhi ${ }^{* *}$
}

\begin{abstract}
\end{abstract}
A study was conducted for two main objectives, the first one is to dispose the agricultural wastes in a simple way by burning them in a system contain an eco-furnace, the second objective is to test the possibility of using the previous system to dispose the wastes for warming poultry houses. Temperature drop inside the poultry houses especially in the winter months leads to lower the growth rate of poultry in addition to detrimental effect on feed conversion and poultry flock performance. On the other hand there is no doubt that the use of electricity or butane gas for heating farms especially in developing countries leads to increased production costs resulting in an increase in the price of the commodity marketing. This study was carried out to evaluate and analyze the effects of eco-furnace on warming poultry houses. In Egypt, storage of corn stalks and rice straw bundles present serious fire hazards and environmental pollution when farmers burn it to save time for preparing the land for the next crop. The major benefits of burning poultry litter, that all of the phosphorus, potassium, calcium, magnesium and other valuable micro-elements in the litter would be captured in the ash, in addition to dispose toxic and harmful elements as microbes and viruses by burning. Preliminary experiments were conducted in order to select the most efficient eco-filter liquid in reserving exhaust ash and experimentation has been conducted on three different types of liquids (water, water with solved lime, oil). Four types of residues materials (rice straw, corn stalks, cotton stalks and poultry litter); and three poultry house warming systems (eco-furnace, butane gas, and electricity) were taken as treatments in this study. The measurements included filtration liquid efficiency (\%), poultry body weight ( $\mathrm{kg} / \mathrm{bird})$, poultry mortality (\%) and costs of poultry house warming process. The best filtration liquid was water with solved lime with efficiencies as follow 13,11,16 and $19 \%$ for rice straw, corn stalks, cotton stalks and poultry litter, respectively.

\footnotetext{
${ }^{*}$ Lec. Agric. Eng. Dept., Fac. Agric. Mansoura Univ.

*** Agric. Eng. Res. Institute, Dokki-Giza.
} 
The mean body weight increased from 1.23 to $1.58 \mathrm{~kg} / \mathrm{bird}$ at age of 35 day when using the eco-furnace system. The mortality decreased from 5.2, 3.7, 2.8, 5.6 and $6.4 \%$ to 3.9, 1.6, 1.3, 2.2 and $2.4 \%$ at ages of $1 w k, 2$ $w k, 3 w k, 4 w k$ and $5 w k$, respectively when using the eco-furnace. The ecofurnace saved about 63 and 86\% of the energy cost compared with the conventional systems of butane gas and electricity. So, conserving rice straw, corn stalks, cotton stalks and poultry litter to energy can solve serious environmental polution and providing millions of pounds in energy savings to poultry producers each year.

Key words: Agricultural residues materials, Furnace, Combustion, Warming, Poultry houses.

\section{ITRODUCTION}

Poultry (particularly chicks) in their initial phase (first two weeks of life) are very sensitive to low temperatures, which may negatively affect their development, leading to huge financial losses, especially in conditions of harsh winters, so failure of a poultry house space heating system can be catastrophic. In Egypt, heating broiler houses is essential in winter season, whereas cooling may be required in summer. Energy costs constitute a significant portion, often over half, of cash expenses for poultry producers (Cunningham, 2008). Heat energy is added by propane fired heaters or electric heaters with direct air heating to the facilities from the metabolic production of birds in Egypt, but recent shortages in propane have led to increased interest in biomass materials for heating poultry houses. In some locations growers are saving money by using furnaces to burn chips, coal, used motor oil or hay to heat their poultry houses, but there isn't a large quantity of them. So, burning rice straw, corn stalks and poultry litter, produce as many Btus as propane and electricity and there is a large quantities of them.

Field crop residues are considered one of the critical problems, which face the Egyptian farmer especially after harvesting. In Egypt, about 30 million tons of agricultural residues are generated each year (MOA 2007). Crop residues are considered the most critical problems facing the Egyptian farmer, especially after harvesting the crop. Egyptian farmers burn yearly about 2-3 ton/fed. of rice straw and 5.87 million ton of corn stalks respectively as a means for disposing it and to save time for 
preparing the land for the next crop (Helmy et al., 2003). Poultry production has shifted from smaller family owned-farms, to large-scale industrial facilities known as Concentrated Animal Feeding Operations. Commercial poultry production is one of the largest agricultural industries in Egypt. In poultry production, poultry are the major birds produced. In 2008 , poultry meat accounted for $87 \%$ where as other birds accounted for 13\% only (FAOSTAT, 2009).

Removal of agricultural residues for framers by burn is wrongly way to make pollution surroundings. Poultry litter (manure plus absorbent biomass), is a waste product of the poultry industry that comes from floor-raised birds and consists of their manure, bedding material (usually wood shavings), waste feed, and feathers. According to (Avila et al., 2007) the litter thickness is between $8 \mathrm{~cm}$ and $10 \mathrm{~cm}$, depending on the density Established. The wood chip and fecal matter mixture is termed litter and must be removed from the house floor periodically to promote good health and hygiene among the flocks. It is used in land applications as a fertilizer because it is rich in nutrients. But over application of this material could lead to an overabundance of water nutrients resulting in eutrophication of water bodies, the spread of pathogens, the production of phytotoxic substances, air pollution and emission of greenhouse gases. At the local level, poorly managed poultry litter stockpiles can cause large effluents of malodorous compounds primarily ammonias that reduce air quality (Siefert et al., 2004). Spreading poultry litter as a fertilizer that is high in $\mathrm{N}$ and phosphorus (P) content provides a suitable, economic, and convenient supplement to inorganic fertilizers. The excess $\mathrm{P}$ and $\mathrm{N}$ is quickly transported by runoff water into the neighboring rivers, lakes, and streams. These high levels of $\mathrm{NO}_{3}$ can cause cancer, respiratory disease in humans, foetal abortion in livestock and methaemoglobinaemia, a blood disorder in infants commonly known as 'blue baby disease' (Henihan et al, 2003) also reported that heavy rainfall can sweep the poultry litter applied to land into nearby ditches, streams and lakes. Surface water pollution by nutrients can lead to eutrophication, which is the excessive growth of algae that consumes aquatic nutrients and oxygen, and block sunlight But this poultry litter, is a viable and renewable energy source (Habetz et al., 2006). So scientists and poultry industry leaders are being 
challenged to find alternative ways of managing poultry litter (Deterling, 2002). It is considered as an optimal technology to dispose the animal waste with energy recovery (Sharpley et al., 2001). One very good solution is utilizing excess poultry litter as a fuel to generate clean, renewable energy (Martin, 2000). Waste-to-energy is an excellent solution, and ultimately solves two problems: (1) Provides high value alternate use of poultry litter to reduce excessive land application (2) Provides valuable and renewable energy to help offset high energy costs.

Corn is a "natural pellet" which facilitates fuel storage and handling. Corn has a higher heating value (HHV) of 6,900 7,000 Btu/pound, which equates to a lower heating value (LHV) of $\sim 6,000 \mathrm{Btu} / \mathrm{lb}$ at $15 \%$ moisture content (wet basis). Corn stalks and rice straw are in general a low quality feed for Cattle, so this study investigated the performance of corn stalks, a locally available agricultural waste material in warming poultry houses. The type of combusted gas was natural gas with a heating value of 31.65 MJ per $\mathrm{m}^{3}$ (Heslinga and van Harmelen, 2006) or propane with a heating value of $25.3 \mathrm{MJ} / \mathrm{L})$. Electricity use $(1 \mathrm{kWh}=3.6 \mathrm{MJ})$ per house. When propane is combusted, $0.060 \mathrm{~kg}$ of $\mathrm{CO}_{2}$ per $\mathrm{MJ}$ is generated for generating electricity; $0.17 \mathrm{~kg}$ of $\mathrm{CO} 2 / \mathrm{MJ}$ is emitted. (Internet research, 2010\&2014).

Filtration is a process in which there comes to separating of dispersed particles from the dispersion medium. Dispersion medium may be gaseous (air). The application can be for cabin, air and flue gas filters, masks, medical equipment, electronics, clothes, etc. (Hruza, 2005).

Researchers have shown that cold stress significantly influences the health, welfare, and production performance of animals in the cold region ( $\mathbf{L i}$ et al., 2006). A wide range of technologies is available for heating in poultry sheds. There are a number of advantages and disadvantages to each type of equipment, and poultry producers need to consider many factors prior to investment, including capital costs and operating costs, access requirements, heat output, heat distribution and unit distribution/placement (Czarick, 2008).Much research has shown that poultry litter having calorific values equivalent to low-rank coals (on the order of $5000 \mathrm{BTU} \mathrm{lb}^{-1}-11600 \mathrm{~J} \mathrm{~g}^{-1}$ ) can be combusted to generate energy (Plasynski et al., 2002 and Miller et al., 2002) (Davalos et al., 2002). Pilot studies have been executed to develop small reactors that will provide 
electricity to power poultry houses through burning poultry waste (Stranahan, S. Q., 2004). Other research has shown that many useful chemicals and materials can stem from the thermal degradation of poultry waste (Shinogi, Y. and Kanri, Y., 2003). A sample of broiler litter that has moisture of $16.3 \%$, volatile matter of $61.4 \%$, fixed carbon of $13.3 \%$, and an ash of $9 \%$ will have a moisture and ash free heat value of $18,010 \mathrm{~kJ} \mathrm{~kg}^{-1}$ (Dagnall, 1993). Poultry litter has been shown to be a viable, renewable biomass fuel. The heating value averages around $4100 \mathrm{Btu} / \mathrm{lb}(9550 \mathrm{~kJ} / \mathrm{kg}$ ) (Mukhtar, 2002), and is usually quite dry, around $25 \%$ moisture content, when compared to other biomass sources. The stoichiometric combustion of poultry litter would result in an adiabatic flame temperature of approximately $2000^{\circ} \mathrm{F}-2100^{\circ} \mathrm{F}$, which is more than adequate to prove the viability of poultry litter as a thermal energy source. Broiler performance is directly influenced by environmental conditions (Blahova et al., 2007). Low ambient temperatures in combination with insufficient air velocity in broiler houses can have a negative effect on, for example, body weight gain, feed efficiency, health, and mortality rate (Aksit et al., 2008).

Therefore, the objective of the present study was to help growers for warming their farms with a cheap and available material like rice straw, corn stalks and poultry litter that lower ammonia levels, which irritate poultry eyes and respiratory systems. This heating method is not only healthier for the birds, but also yields a lower mortality rate, higher weight gains and better feed conversions.

\section{MATERIALS AND METHODS}

To conduct the experimental work a new unit of agricultural residues ecofurnace was constructed from a local and a valuable cheep materials. A private poultry open house with dimensions $(55 \times 10, \mathrm{~m})$ and height of $3.40 \mathrm{~m}$ with 5000 bird at Meet-Salseel, EL- Daqahliyah, Egypt was used in this study during the period from December to March. Three sections from the whole house was used for evaluation the three warming systems (eco-furnace, butane gas, and electricity). Each section contains 100 bird.

Furnace description and operations:-

Burning of agricultural residues was directly conducted in the consumption chamber of an eco-furnace 
which was installed outside the poultry house. The produced heat of burning process was assigned for heating fresh air in order to warming the poultry house. It was taken into consideration that the exhaust gasses were filtered before discharge to the external environment. The common and developed eco-furnace consists of the parts shown in figure (1 A and B), respectively.

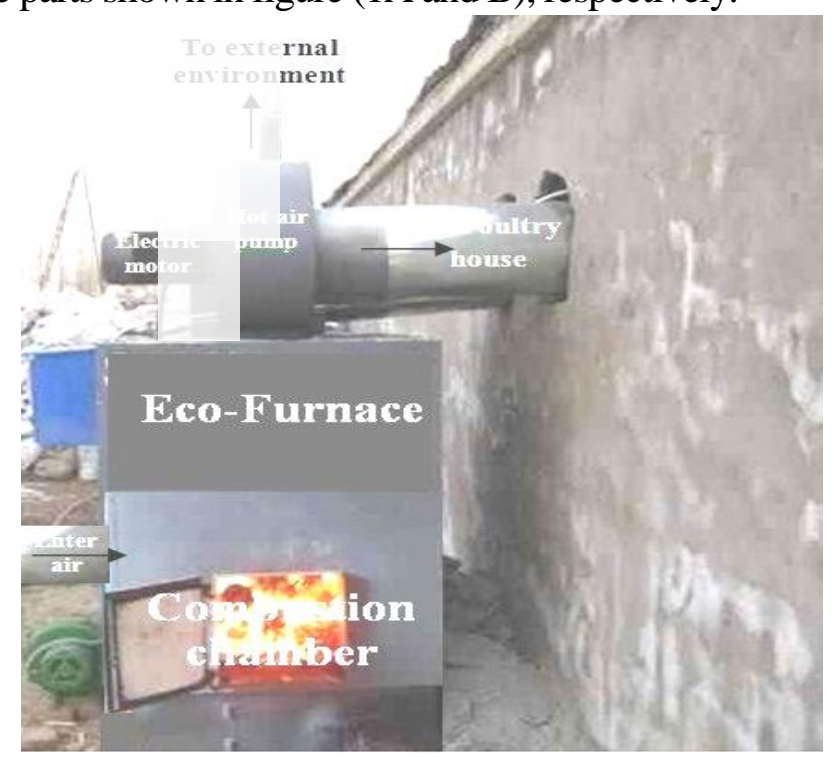

Figure (1A): The common furnace used for warming the poultry houses.

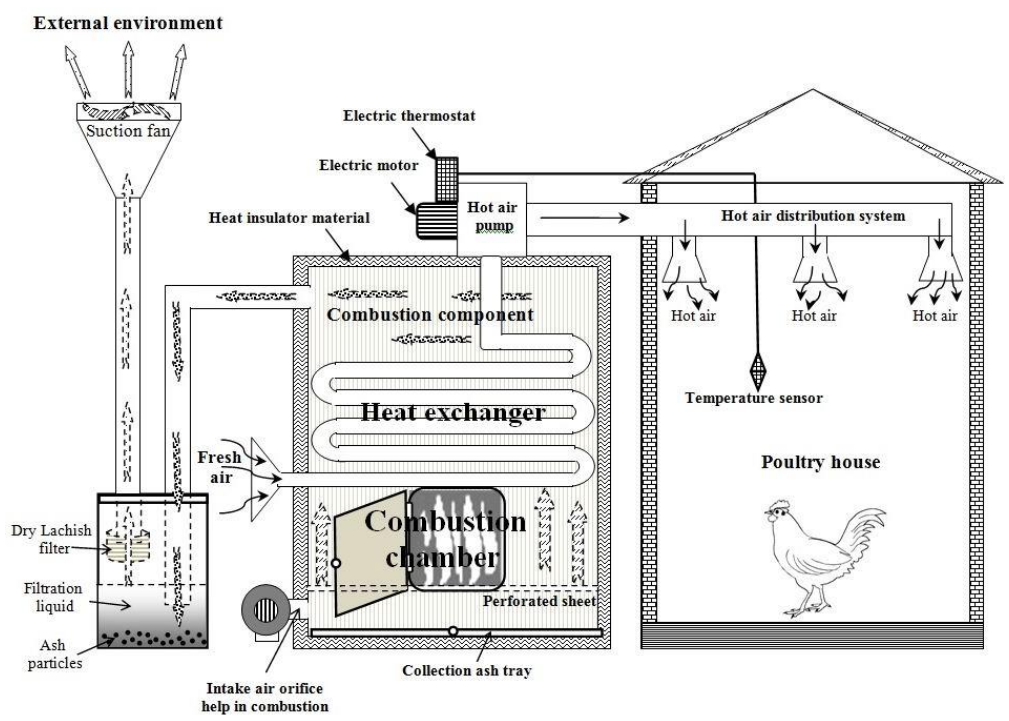

Figure (1B): A diagram illustrates the main parts of the developed eco-furnace system 


\section{(A) Combustion chamber:}

The burning unit (furnace) was made of galvanize steel sheets with thickness of $0.7 \mathrm{~mm}$, its dimensions are $(2.5 \times 1.75 \times 1, \mathrm{~m})$ with hinged door for providing burning materials inside the combustion chamber. All parts of the burning unit were tightly thermally insulated by heat insulator material (fiberglass wool) covered hall outside surface of the combustion room. Perforated sheet and movable tray were provided at the bottom of the combustion chamber for collecting ash, and slot. A suction fan was also provided at the bottom of the combustion chamber for air replacement during the burning process.

\section{(B) An air-to-air heat exchanger:}

A copper tube with sufficient length for heating fresh air while bathing through the hot exhausted air without any mixing was used as illustrate in figure (2).

Air pump with electric thermostat for adjusting the temperature inside the poultry house as recommended was attached at the outlet of the heat exchanger. The pump was assigned for suction of fresh air through the heat exchanger and pushing the resulted hot air inside poultry house.

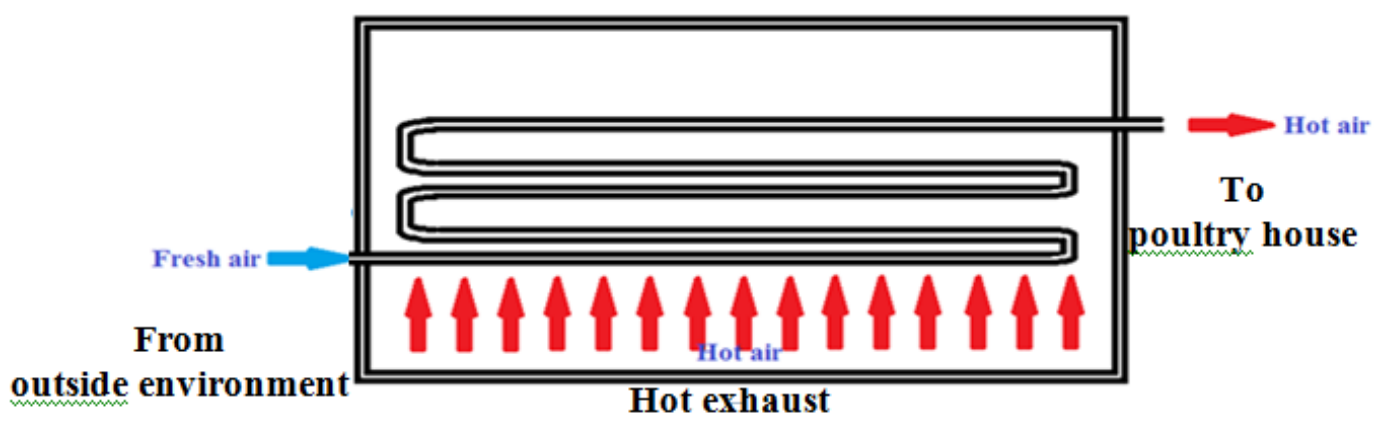

Figure (2): An air-to-air heat exchanger

\section{(C) Exhaust filtration unit:}

The eco-furnace was provided with a unit for filtration of the exhaust polluted particles and toxic gases before rising to the external environment. The filtered unit consists of tight bath filter liquid and an exhaust pipe dipped in it. There was another suction pipe above the filter liquid surface with a dry filter (dry Lachish) to carry out the filtered exhaust to the external environment. A suction fan was also used to help in movement of the exhaust components into the filtering unit. 


\section{Pruning material samples preparation and descriptions:}

Some considerations were taken in collecting the burning residues samples based on its characteristics and moisture contents. The samples of rice straw, corn stalks, cotton stalks and poultry litter were divided into equal volumes and air-dried after cutting it to a suitable length for combustion room dimensions, as summarized in the following table (1) Table (1): the physical and mechanical properties of agricultural residues burning samples

\begin{tabular}{|l|c|c|}
\cline { 2 - 3 } \multicolumn{1}{c|}{} & Thickness, $\mathrm{mm}$ & Moisture content, $\%$ \\
\hline rice straw & 4.5 & 12.3 \\
\hline corn stalks & 40.8 & 9.1 \\
\hline cotton stalks & 20.3 & 8.6 \\
\hline poultry litter & - & 8.2 \\
\hline
\end{tabular}

\section{Studied parameters:}

(1) Residues type: four types of residues were used (rice straw, corn stalks, cotton stalks and poultry litter).

(2) Poultry house warming system: three heating systems (eco-furnace, propane and electricity)

(3) Eco-furnace filtration liquid: three types of exhaust filtration liquids (water, water with solved lime and oil).

\section{Measurements:}

(1) Eco-furnace filtration liquid efficiency, \%: A sample of $5 \mathrm{~kg}$ from each type of agricultural residues was burned and filtrated in 1 liter of filtration liquid. Filtration efficiency was determined from the following equation:

Where:

$$
\text { Filtration efficiency }=\frac{W l_{\text {after }}-W l_{\text {befor }}}{W l_{\text {after }}} \times 100
$$

$W l_{\text {after }}=$ filtration liqued weight after the filtration process, $\mathrm{kg}$.

$W l_{\text {befor }}=$ filtration liqued weight befor the filtration process, $\mathrm{kg}$.

(2) Poultry folk performance:

The effects of an eco-furnace on poultry folk performance were analyzed based on:

A- The initial and final body weight (BW) of chickens was measured during the experimental period (5 weeks). 
B- Mortality was recorded daily and calculated as a percentage. The BW gain was corrected for dead birds.

(3) Energy cost: - The total energy consumption was daily calculated for heating of the broiler houses during the experimental period. The consumption of electricity was also recorded using an electric meter. The total energy cost was calculated according to the local currency rate during the experimental period.

\section{RESULTS AND DISCUSSION}

\section{(1) Effect of filtration liquid type on filtration efficiency.}

The effect of filtration liquid type on filtration efficiency, $\%$ was recorded (Fig. 4). The obtained higher levels of filtration efficiencies, $\%$ for rice straw, corn stalks, cotton stalks and poultry litter, were 13, 11, 16 and 19 $\%$ with lime dissolved in water due to the high levels of carbon, which was deposited by lime. The lower levels of filtration efficiencies, $\%$ for rice straw, corn stalks, cotton stalks and poultry litter, were 11.5, 9.2, 13 and $14 \%$ with oil due to capture of pollutant particles and washing it away into the oil filter. It was observed that by using oil, there was a high flow resistance and a harmful polluted oil vapor generated. In addition to the high oil price. It was noticed that filtration efficiencies, \% increased with filtration liquid type, according to the following descending order (water + lime $>$ water $>$ oil).

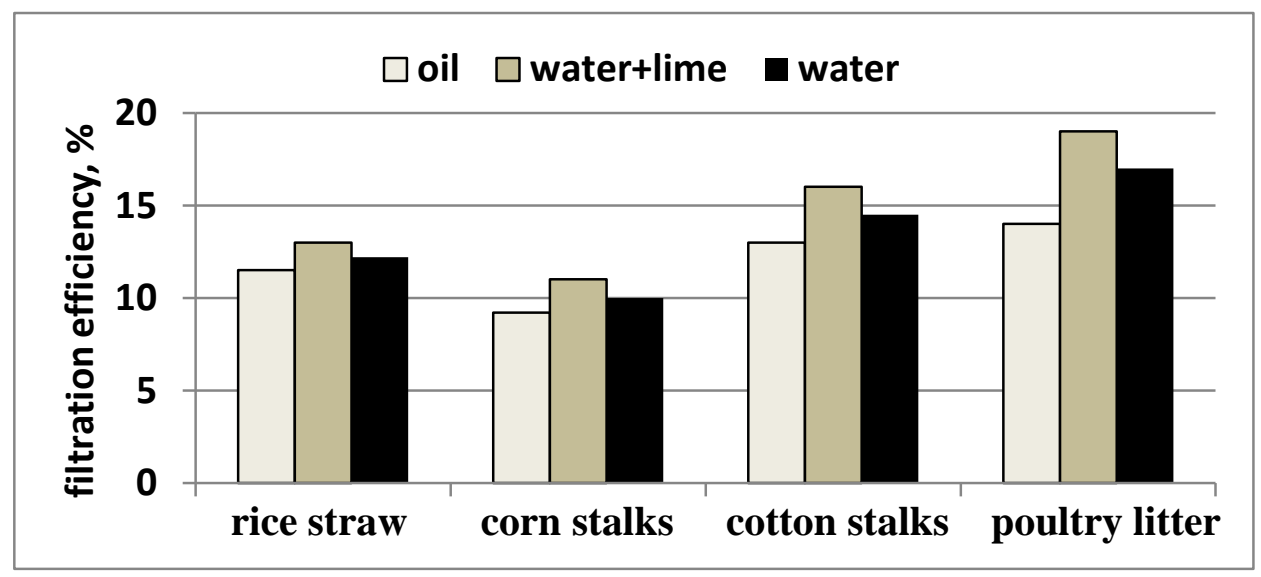

Figure (4) : Effect of filtration liquid type on filtration efficiency, \% for different types of burning residues. 


\section{Effect of eco-furnace on flock performance:}

The effect of the developed eco-furnace on the body weight (BW) gain of chickens at 35 day of age was recorded (Fig. 5). The mean BW gain, $\mathrm{kg} / \mathrm{bird}$ when burning the residues materials in the eco-furnace was 1.58 $\mathrm{kg} / \mathrm{bird}$. There wasn't a significant increased in the BW gain, $\mathrm{kg} / \mathrm{bird}$ when chickens were warmed with the eco-furnace compared with the common warming methods by propane and electricity (1.58 vs. 1.6 and $1.63 \mathrm{~kg} / \mathrm{bird})$, respectively. But there was a significant increased in the BW gain when chickens were warmed in comparison with the chicken grown in an untreated farm $1.23 \mathrm{~kg} / \mathrm{bird}$. This result is consistent with a previous study conducted by Bokkers et al. (2010) who reported that the daily weight gain of broilers tended to increase due to improved climate conditions in the chicken house that used the heat exchanger. In the present experiment, the average $\mathrm{BW}$ gain, $\mathrm{kg} / \mathrm{bird}$ of chickens with the eco-furnace decreased by 1.25 and $3.07 \%$ in comparison with the common warming methods by butane gas and electricity while it was increased by $22.15 \%$ when compared with the untreated farm. The heat pump improved the internal air quality by supplying fresh air to the chickens house, which may reduce the inside dust and NH3 gas concentration. It was noticed that BW gain, $\mathrm{kg} / \mathrm{bird}$ increased with warming system, according to the following descending order (electricity $>$ butane gas > eco-furnace). Meanwhile, the lost percentage of mortality for the un-treated house was $2.8 \%$ at the third week. The highest percentage of mortality for the un-treated house was $6.4 \%$ at the fifth week (Fig. 6).

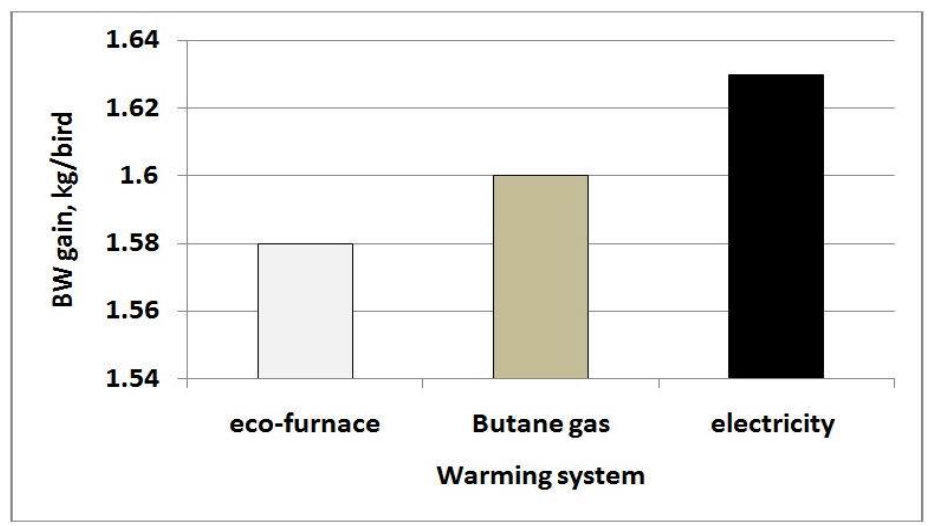

Figure (5) : Effect of heating system on BW gain of broiler chickens at 35 day of age 


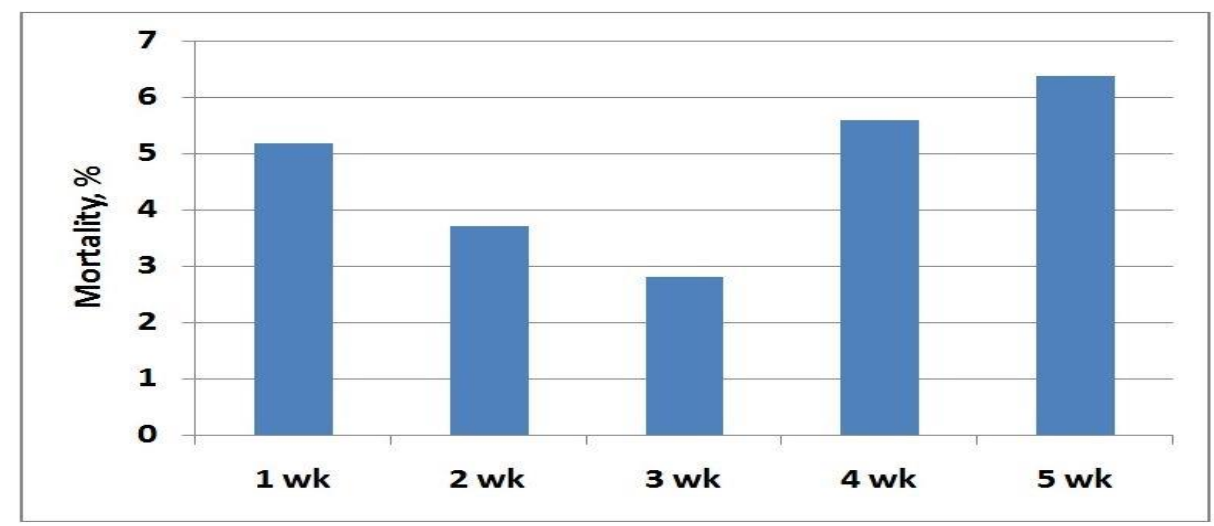

Figure (6) : The mortality, \% with the un-treated house during the experimental period (1-35 day)

In general, the maximum mortality, $\%$ during the study weeks were recorded with the untreated house, while the minimum were with the electricity system. The difference, $\%$ between the eco-furnace and the electricity systems were $12.82,31.25,15.38,13.64$ and $29.17 \%$ after the $1 \mathrm{wk}, 2 \mathrm{wk}, 3 \mathrm{wk}, 4 \mathrm{wk}$ and $5 \mathrm{wk}$, respectively, but using the eco-furnace system can solve serious environmental problems and provide millions of pounds in energy savings to poultry producers each year (Fig. 9). It was noticed that the mortality, \% decreased with heating system, according to the following descending order (electricity $>$ butane gas $>$ eco-furnace).

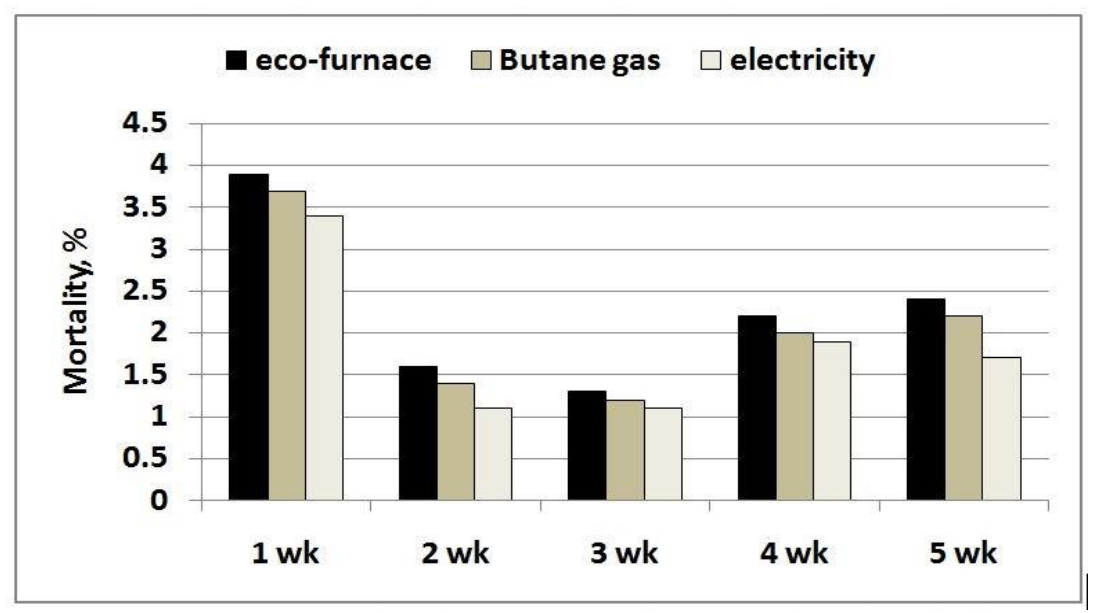

Figure (7): Effect of heating system on the mortality, \% of chickens during the experimental period (1-35 day) 


\section{Estimation of energy cost:}

The total energy price for different studied heating methods showed that the ecofurnace saved about 63 and $86 \%$ of the energy cost compared with the conventional systems that used butane gas and electricity, which is also in agreement with Choi et al. (2010). Generally, butane gas and electricity are used in Egypt as energy source for heating poultry houses, which is costly. As the country is extremely susceptible to rises in butane gas and electricity prices, it needs to reduce butane gas and electricity use. In the present experiment, though the residues materials consumption which are sufficient in warming poultry houses and not more economical when total energy consumption was considered. Therefore, birds were raised much more economically in the new system than those in the conventional systems under prevailing climate conditions. So, the ecofurnace system energy source used in the chicken house will be an effective alternative, renewable, and clean energy source for Egypt.

\section{CONCLUSION}

The best filtration liquid was water with solved lime with efficiencies as follow 13, 11,16 and $19 \%$ for rice straw, corn stalks, cotton stalks and poultry litter, respectively. The mean body weight increased from 1.23 to $1.58 \mathrm{~kg} / \mathrm{bird}$ at age of 35 day when using the eco-furnace system. The mortality decreased from 5.2, 3.7, $2.8,5.6$ and $6.4 \%$ to $3.9,1.6,1.3,2.2$ and $2.4 \%$ at the $1 \mathrm{wk}, 2 \mathrm{wk}, 3 \mathrm{wk}, 4 \mathrm{wk}$ and $5 \mathrm{wk}$, respectively when using the eco-furnace. The eco-furnace saved about 63 and $86 \%$ of the energy cost compared with the conventional systems that used butane gas and electricity. From the results of the experiment, it is concluded that the eco-furnace system could increase the production performance of chickens due to increase inside air quality with improved housing environment. It is also concluded that the eco-furnace system has lower energy cost than the conventional heating system for chickens. Also combustion of residues materials like rice straw, corn stalks, cotton stalks and poultry litter used to recover heat and ash fractions containing phosphorus and potassium that can be used in fertilization.

\section{REFERENCES}

Aksit M., k. Altan, A. B. Karul, M. Balkaya and D. Ozdemir, 2008. Effects of cold temperature and vitamin E supplementation on oxidative stress, Troponin-T level, and other ascites-related traits in broilers. Arch. Geflugelkd. 72:221-230. 
Avila V. S., A. Kunz, C. Bellaver and P. S. Rosa, 2007. Good broiler production practices. Concordia, Brazil: Embrapa Swine and poultry, Technical Circular 51, 2007.

Blahova J., R. Dobsikova; E. Strakova and P. Suchy, 2007. Effect of low environmental temperature on performance and blood system in broiler poultry (Gallus domesticus). Acta Vet. (Brno) 76:17-23.

Bokkers, E. A. M., H. H. E. Van zanten and H. Van den brand, 2010. Field study on effects of a heat exchanger on broiler performance, energy use, and calculated carbon dioxide emission at commercial broiler farms, and the experiences of farmers using a heat exchanger. Poultry. Sci. 89:27432750.

Choi, H. C., J. H. Park, J. I. Song, M. J. Kim, H. T. Bang, Kang H. G., 2010. Evaluation on heating effects of geothermal heat pump system in furrowing house. J. Lives. House. Env. 16:205-214.

Cunningham D., 2008. Broiler Production Systems in Georgia 2007-2008 Costs and Returns Analysis. Department of Poultry Science. Available at http://pubs.caes.uga.edu/caespubs/pubs/PDF/B1240-3.pdf._Accessed $\underline{9 / 8 / 08}$.

Czarick M. D., 2008. Alternative heating systems: an overview. Poultry environment \& energy conservation poultry housing tips, Vol. 20(14).

Dagnall, S. P., 1993. Poultry Litter as a Fuel. World's Poultry Science Journal. 49:175- 177.

Davalos, J. Z.; M. V. Roux; P. Jimenez, 2000. Evaluation of poultry litter as a feasible fuel. Thermo him. Acta 2000, 394, 261-266.

Deterling Del, 2002 . Chicken Litter Logic, Progressive Farmer, Mid-Jan 2002.

FAOSTAT, 2009. Food and Agricultural Organization production statistics, Livestock-primary and processed. Rome, Italy: FAO http://faostat.fao.org/site/569/DesktopDefault.aspx?PageID=569 date of access: 26 February 2010. 
Habetz, D. C., S. F. Echols and M. A. Richard ,2006. Development of Successful Poultry Litter-to Energy Furnace. ASABE Metting Paper. Paper Number 064185. St. Joseph, Mich. July 2006.

Heslinga D. C. and A. K. Van Harmelen., 2006. Vastellingsmethodieken voor CO2-emissiefactoren van aardgas in Nederland. [Verifying methods for $\mathrm{CO} 2$ emission factors of natural gas in the Netherlands]. TNO-report 2006-A-R0079/B. TNO, Apeldoorn, the Netherlands.

Helmy M. A., A. A. Abd EL-Rhman; M. T. Ebaid, and M. A. Hassan, (2003). Expectant production of biogas and fertilizer from different residues fermentation using biogas unit. Misr J.Ag.Eng., 20(4): 949- 964.

Henihan A. M., M. J. Leahy, J. J. Leahy, E. F. Cummins, and B. P. Kelleher, 2003. Emissions modeling of fluidized bed co-combustion of poultry litter and peat. Bioresource Technology 2003;87:289-94.

Internet research, 2010.

http://www.propanegas.ca/FileArea/PGAC/Propane $\% 20$ properties. pdf; accessed October2010.

Internet research, 2014.

http://www.chinamet.com/products/detail-80262.aspx

Li S. Z., B. B. Ren, H. M. Yang and Y. Y. Yang, 2006. Effect of cold stress with different intensities on HSP70 expression in Wistar rat muscle, spleen, and liver. Chin. J. Appl. Environ. Biol. 12:235-238.

Martin J. r. D. Ph., John, Sc. D. Lefcort; D. M. Malcolm, 2000. An Analysis of the Feasibility of Using Broiler Litter as a Fuel, Paper presented to the Seventeenth Annual International Pittsburgh Coal Conference, Pittsburgh, PA, September 2000.

Miller B. G., S. F. Miller and A. W. Scaroni, 2002. Utilizing Agricultural ByProducts in Industrial Boilers: Penn State's Experience and Coal's Role in Providing Security for our Nation's Food Supply. Presented at $19^{\text {th }}$ Annual International Pittsburgh Coal Conference, Pittsburgh, PA, Sept 23- 27, 2002.

MOA 2007. Economic Affairs Sector. Ministry of Agric. and Land Rec. Cairo, Egypt. 
Mukhtar G. D., A. A. Saqib, R. H.Annamalai and S. A. Kalyan, 2002, CoFiring of Coal and Broiler Litter (BL) Fuels for Power Generation: BL Fuel Quality and Characteristics, ASAE Paper No. 024189, Chicago, Illinois, St. Joseph, Michigan: ASABE

Plasynski S. I., P. M. Goldberg and Z. Y. Chen, 2002. Using Animal Waste Based Biomass for Power and Heat Production while Reducing Environmental Risks. Presented at 19th Annual International Pittsburgh Coal Conference, Pittsburgh, PA, Sept 23-27, 2002.

Sharpley A. N., R. W. McDowell and P. J. A. Kleinman, 2001. Phosphorus loss from land to water: Integrating agricultural and environmental management. Plant Soil 2001, 237, 287-307.

Shinogi Y. and Y. Kanri, 2003. Pyrolysis of plant, animal and human waste: physical and chemical characterization of the pyrolytic products. Bioresour. Technol. 2003, 90, 241-247.

Siefert R. L., J. R. Scudlark, A. G. Potter, Simonsen K. A. and K. B. Savidge, 2004. Characterization of Atmospheric Ammonia Emissions from a Commercial Poultry House on the Delmarva Peninsula. EnViron. Sci.Technol. 2004, 38, 2769-2778.

Stranahan S. Q., 2004. Farmers Face a Big Stinking Mess. Fortune, Apr. 1, 2002, pp 32-34; Academic Search Premier, Aug 15, 2004.

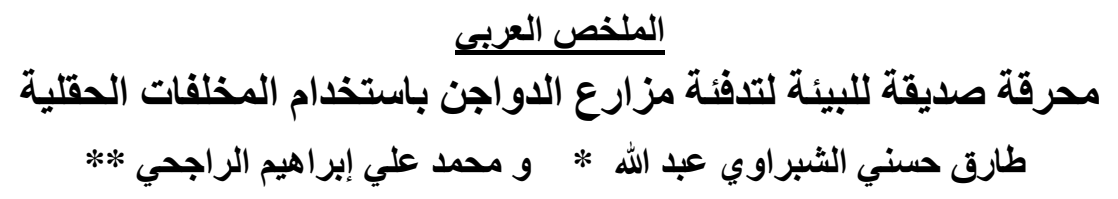

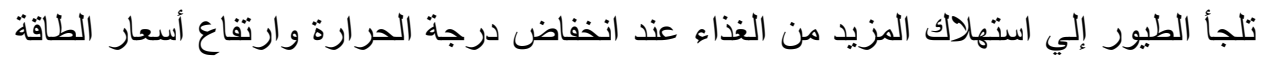

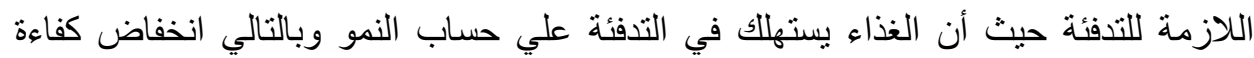

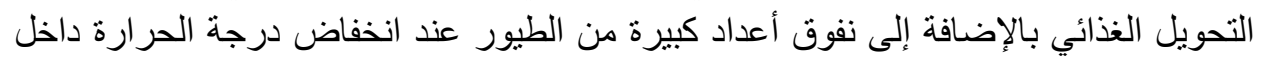

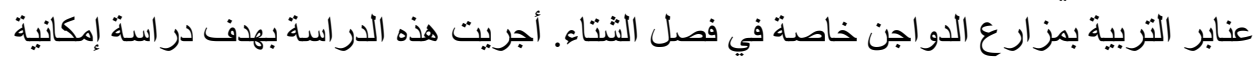

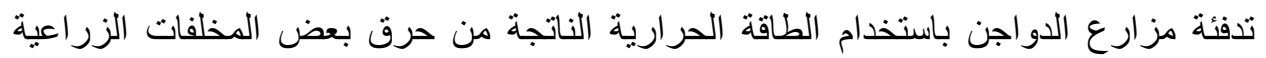

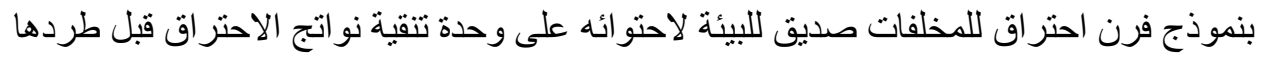

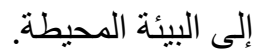

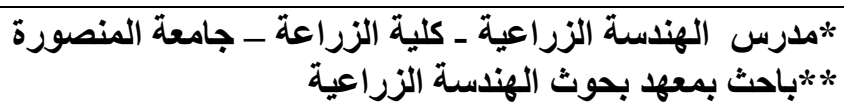


وتم اختبار ثلاثة أنواع مختلفة من سو ائل الفلترة وهى (الماء ـ الماء المحتوى على الجير الذائب

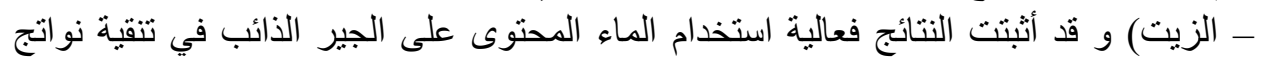

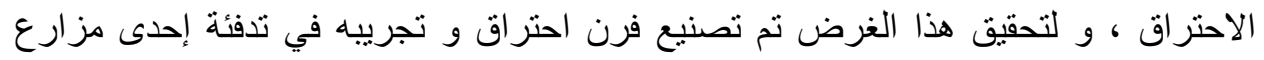

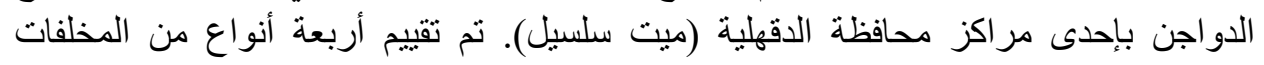

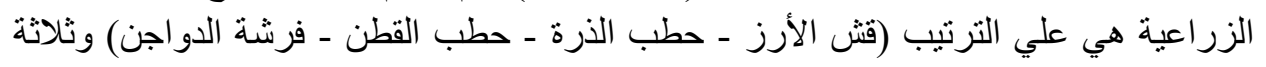

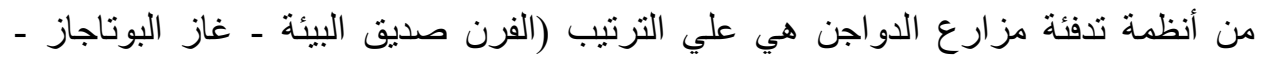

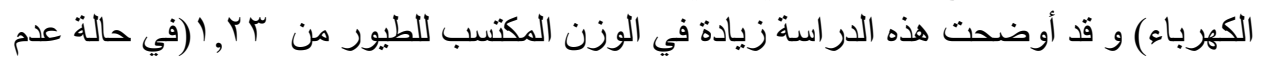

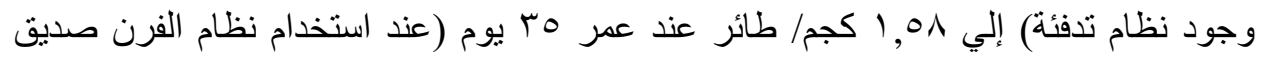

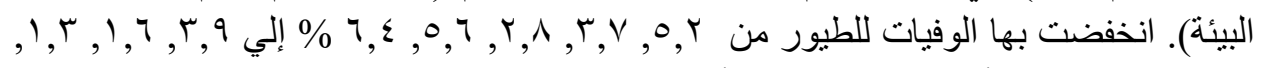

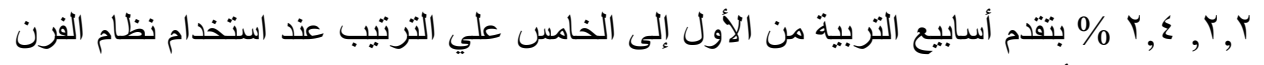

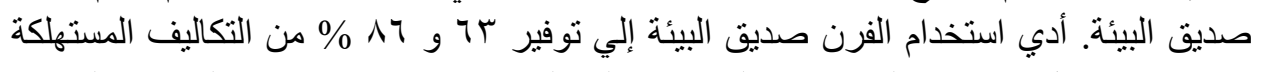

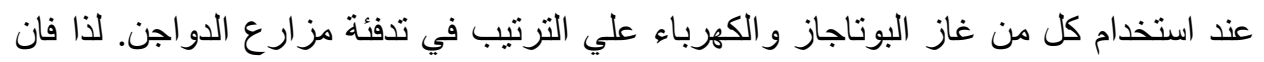
استخدام المخلفات الزر اعية في التدفئة تحل العديد من المشاكل البيئية و الاقتصادية. 